\title{
Teaching and learning quaternary prevention
}

\author{
0 ensino e a aprendizagem da prevenção quaternária
}

\section{La enseñanza y el aprendizaje de la prevención cuaternaria}

Luís Filipe Gomes. Algarve University Medical School (UAlg). Faro, Portugal. gomes.filipe@netcabo.pt

Gustavo Gusso. Discipline of General Practice. São Paulo University (USP). São Paulo, SP, Brazil. gustavo.gusso@usp.br (Corresponding author)

Marc Jamoulle. Department of General practice. University of Liège (DUMG ULg). Belgium. marc.jamoulle@doct.ulg.ac.be

\section{Abstract}

This article presents an overview of different techniques and skills necessary for teaching and learning quaternary prevention (P4). It adopts the Expertise Model that defines the competences required in P4 for each level: novice, competent, proficient, and expert. This framework should be used as a step-wise roadmap for teachers in order to achieve high levels of performance. This proposal is complemented by a list of methods applied in teaching and assessment of learners' performance and competence. By covering a range of learning and teaching issues, those who aim to teach quaternary prevention can explore the proposed framework. Quaternary prevention is a research and teaching fertile medical field that entails the integration of different areas such as health service organization, epidemiology, communication skills, and andragogy either at the macro or the micro levels of health related activities.

\section{Resumo}

Este artigo apresenta uma visão geral das diferentes técnicas e habilidades necessárias para o ensino e a aprendizagem da prevenção quaternária (P4). Ele adota 0 Expertise Model que define as competências exigidas na P4 para cada nível: iniciante, competente, proficiente e expert. Essa estrutura pode ser utilizada como um roteiro passo a passo para os professores, a fim de alcançar elevados níveis de desempenho. Esta proposta é complementada por uma lista de métodos usados no ensino e na avaliação de desempenho e competências dos alunos. Ao cobrir uma série de questões de ensino e aprendizagem, aqueles que visam ensinar prevenção quaternária podem explorar a grade proposta. A prevenção quaternária é um campo fértil para a investigação e o ensino da medicina que envolve a integração de diferentes áreas, como a organização de serviços de saúde, epidemiologia, habilidades de comunicação e andragogia, tanto no nível macro como no micro das atividades relacionadas à saúde.

\section{Resumen}

Este artículo presenta una visión general de las diferentes técnicas y habilidades necesarias para la enseñanza y el aprendizaje de la prevención cuaternaria (P4). El adopta el Expertise Model que define las competencias requeridas en P4 para cada nivel: principiante, competente, proficiente y experto. Esta estructura puede ser utilizada como un guía paso a paso para los profesores con el fin de alcanzar altos niveles de rendimiento. Esta propuesta se complementa con una lista de métodos utilizados en la enseñanza y la evaluación del desempeño y competencia de los educandos. Al hacer referencia a una serie de cuestiones de enseñanza y aprendizaje, los que tienen como objetivo enseñar prevención cuaternaria pueden explorar el marco propuesto. La prevención cuaternaria es un campo fértil de investigación y enseñanza de la medicina que requiere la integración de diferentes áreas como la organización de servicios de salud, epidemiología, habilidades de comunicación, y la andragogía, ya sea en el nivel macro como micro de las actividades relacionadas con la salud.

\section{Keywords:}

Quaternary Prevention

Teaching

Education, Medical

Family Practice

Internship and Residency

Palavras-chave:

Prevenção Quaternária Ensino

Educação Médica

Medicina de Família e

Comunidade

Internato e Residência
Palabras clave:

Prevencion Cuaternaria

Enseñanza

Educación Médica

Medicina Familiar y Comunitaria Internado y Residencia 
"One of the first duties of the physician is to educate the masses not to take medicine"Sir William Osler (p. 105) ${ }^{1}$

\section{Introduction}

Quaternary Prevention (P4) is defined as "the action taken to identify a patient or a population at risk of overmedicalization, to protect them from invasive medical interventions and provide for them care procedures which are both scientifically and ethically acceptable". ${ }^{2,3}$ It is considered by many a controversial concept, mainly because it follows a different direction from the other prevention concepts (primary, secondary and tertiary prevention) which lead to more interventions. ${ }^{4}$

The concept of $\mathrm{P} 4$ is better integrated by generalists as general practitioners/family physicians (GP/FP) and practice nurses - because these specialists are not committed with specific parts of the body or groups of diseases. ${ }^{5}$ Medicine and its interventions are usually driven towards increasing both quality and expectancy of life; but, when in excess, even apparently simple interventions as screening procedures may have opposite effects. ${ }^{6}$ The impact of unwanted effects from excess of medical interventions only recently (a few decades ago) became an object of epidemiological studies. ${ }^{7}$

Observing the way "market driven influences" favour and induce overdiagnosis, overscreening, incidentalomas, overtreatment and overmedicalisation, it is necessary to remind all medical professionals of the first basic principle of our activity: primum non nocere. ${ }^{8,9}$ Disease mongering, disease marketing and branding of conditions are the weapons handled by the bigpharmas, supported by their effective partners in medical associations and classification boards. ${ }^{10}$ Instrumental to this is the widespread use of fake publications with the benediction of some medical press and academic centres in a broad picture of institutional corruption and the complicity of public health policies which have long ago forgotten their responsibilities towards the people they should serve. ${ }^{11,12}$ To contradict this status quo, and to help doctors to be in the best conditions to understand and avoid these "market driven influences", therefore acting in the best interest of their patients and society as a whole, we need to bring up a wide programme of learning and teaching P4.

\section{The learning/teaching process}

Quaternary Prevention is a decisive and sensitive concept. It should be learned and taught bearing in mind that together with its strengths there are also threats. The main threat is to transform the research in this field in a ghetto or to reduce it into a kind of political militancy. Since health services have undergone a huge transformation, becoming more like an industry, one of the main values of medicine - "primum non nocere" - has become a sort of "different" and "strange" concept, almost an "aberration". ${ }^{13}$ Teachers in the quaternary prevention field should take these issues into consideration.

\section{The learners}

Any learning/teaching process must define the target group. ${ }^{14}$ This paper is intended to address the medical students and doctors, at all levels of medical learning process: (1) undergraduate medical programmes such as Basic Medical Education-BME which focus on students; (2) Specialty Training programmes with a focus on GP trainers and GP trainees (ST); and (3) Continuing Medical Education (CME)/Continuing Professional Development (CPD), aiming the health professionals.

\section{The teachers}

Over recent years a greater proportion of the teaching at undergraduate level (BME) is being provided by general practice based teachers coming from a practice setting. ${ }^{15}$ The same happens with trainers involved in ST, and CME/CPD Tutors. The teaching of $\mathrm{P} 4$ requires special knowledge and skills, as well as a close working relationship between teachers and learners. The main competences for a teacher of quaternary prevention addressed in this article are presented below. 


\section{Communication skills with the patient}

Patients learn since childhood "what is the purpose of a doctor": to complain about pain and other physical symptoms, to talk about diseases or health problems, or, in a relatively recent scenario, to ask for medication, screenings or other procedures. When this process happens and patients learn how to communicate with doctors only about their disease this can produce a behavioural pattern or even a vicious cycle (Figure 1). It is often a skilled doctor who usually breaks this behavioural pattern and explores with the patients about their fears or expectations. Many symptoms such as agitation, thoracic pain, or depression often reflect underlying personal issues, which are not easy for patients to express them. Additionally, the media reinforces this disease behavioural and communication pattern by "selling" the idea that doctors save lives and deal only with diseases and physical symptoms. ${ }^{16}$ Hence, one of the most crucial tasks for health professionals is to detect when a given intervention is not appropriate for an individual patient. A decoding process becomes necessary in order to deeply access and understand patients' feelings, fears, ideas and expectations, as well as associated signs and symptoms, considering patients' wider context. ${ }^{17,18}$

\section{Communication skills with the learners}

Teachers should understand how teachers teach and how adults learn. In teaching P4 we are dealing with adult learners (andragogy). ${ }^{19}$ Learning processes should be based in a relevant environment, actively involving teachers and learners at all stages in order to produce a reflective self-educating practitioner. Adult learning process works better when self-directed, experiential, need-based and problem-based directed. P4 teachers should use learner centred models of teaching to improve the communication with learners. ${ }^{16}$

\section{Personal attributes}

Teachers should have open minds, good health, and master listening and communication skills. Additionally, they should be keen to share competencies and be skilful in organising their teaching activities.

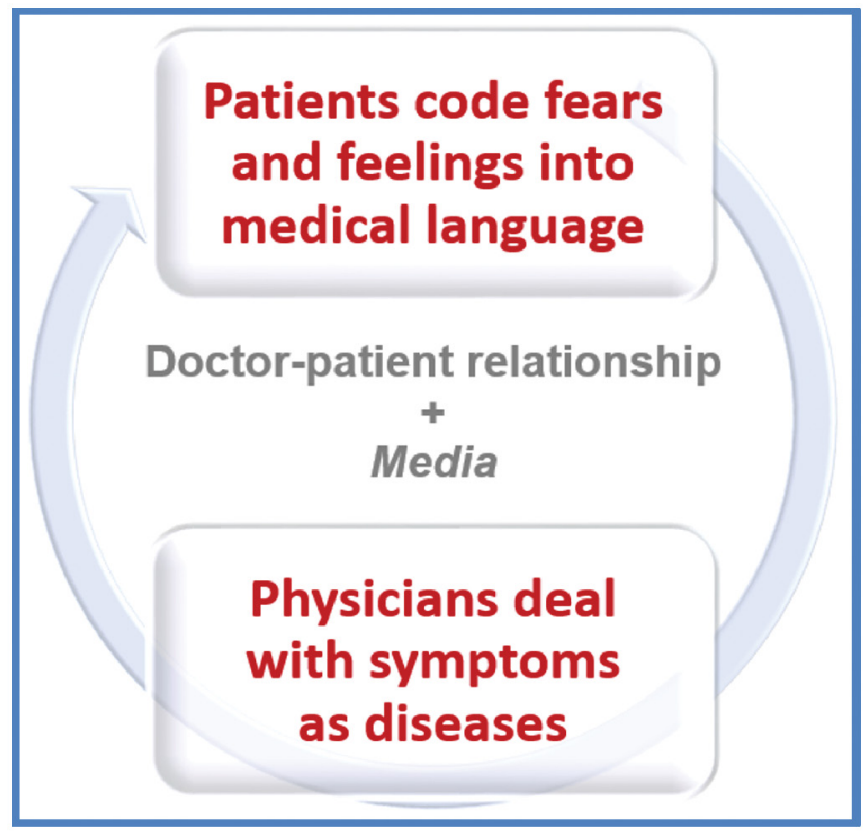

Figure 1. Vicious cycle identified in doctor-patient communication. Source: elaborated by the authors. 


\section{Medical competences}

Teachers should also be experienced as medical doctors and master up-to-date clinical knowledge and skills in order to teach P4. They should always aspire to an outstanding professional attitude and work in typical practice profile, as well as be involved in quality of care improvement and keep appropriate records. Finally, teachers should have a firm commitment to teach $\mathrm{P} 4$ at all levels.

\section{The working environment}

Teaching quaternary prevention can be more of a challenge when the health systems are not rational and well-organised. Rational health systems rely on strong primary health care and skilled generalists working in teams and in a network environment. Additionally, for learners, it might sound contradictory and confusing to practice and learn quaternary prevention in an 'ill-organised' health system, such as systems without a clear regulation, lacking lists of patients per general practitioners (i.e. family doctors being the gatekeepers of hierarchical health systems) and being driven by market. In order to overcome the difficult task of teaching P4, teachers might choose or develop their own strategies, based upon different teaching and learning styles. Hence, quaternary prevention can be practiced and taught at individual level but attains maximum effectivity when aimed towards the population as a whole, which requires a "task force" effort. ${ }^{20}$

\section{The objectives: what we are going to teach?}

To organise the different and complex competences needed to perform quaternary prevention, and the steps for mastering those competences through the learning/teaching process, we decided to apply the Expertise Model: the Dreyfus brothers 4-stage model, defining the characteristics of functioning at each level: Novice, Competent, Proficient, and Expert. ${ }^{21}$

This model was successfully used as "Framework for Continuing Educational Development of Trainers in General Practice/Family Medicine in Europe” by the European Academy of Teachers in General Practice/Family Medicine (EURACT) and partners (College of Family Physicians in Poland; Health and Management Ltd.; ZiZ Education Centre Ltd.; Danish College of General Practitioners; Institute for Development of Family Medicine; Greek Association of General Practitioners; Portuguese Association of General Practitioners; and Turkish Association of Family Physicians). ${ }^{22}$ The objectives of the learning/teaching process are (among others possible) described in Table 1.

Table 1. Domains of Teaching Quaternary Prevention. ${ }^{21}$

\begin{tabular}{|c|c|c|c|c|}
\hline \multicolumn{5}{|c|}{ Personal attributes } \\
\hline Domain & Novice & Competent & Proficient & Expert \\
\hline Ethics & $\begin{array}{l}\text { Familiarity with the concept } \\
\text { of professional and personal } \\
\text { ethics. }\end{array}$ & $\begin{array}{l}\text { Apply ethical principals in dealing with } \\
\text { patients medical needs. } \\
\text { Justify/clarify personal ethics. }\end{array}$ & $\begin{array}{l}\text { Deal with complex ethical } \\
\text { issues in relation to over- } \\
\text { medicalization achieving } \\
\text { shared decisions with } \\
\text { patients. }\end{array}$ & $\begin{array}{l}\text { Identify ethical aspects of } \\
\text { clinical practice. } \\
\text { Understand the full context of } \\
\text { over-medicalization, finding } \\
\text { solutions and applying the } \\
\text { principles of P4 to patients } \\
\text { while influencing colleagues } \\
\text { and learners. }\end{array}$ \\
\hline Self-knowledge & Capability of self-assessment. & $\begin{array}{l}\text { Self-awareness of own emotional } \\
\text { responses in dealing with P4 issues. }\end{array}$ & $\begin{array}{l}\text { Use self-knowledge as a } \\
\text { tool in relating to patients } \\
\text { and team when dealing with } \\
\text { complex situations. }\end{array}$ & $\begin{array}{l}\text { Influence others into } \\
\text { self-knowledge, providing } \\
\text { adequate methods when } \\
\text { needed and establishing the } \\
\text { reports with P4. }\end{array}$ \\
\hline
\end{tabular}

Source: elaborated by the authors from the professional standards for conservation, Institute of Conservation, London, 2008, based on the Dreyfus model of skill acquisition. ${ }^{21}$ 
Table 1. Continued...

\begin{tabular}{|c|c|c|c|c|}
\hline \multicolumn{5}{|c|}{ Person centeredness } \\
\hline Domain & Novice & Competent & Proficient & Expert \\
\hline Communication & $\begin{array}{l}\text { Ability to communicate with } \\
\text { patients. }\end{array}$ & $\begin{array}{l}\text { Easily communicate with patients, } \\
\text { using empathy and non-verbal signs. }\end{array}$ & $\begin{array}{l}\text { Apply communication skills } \\
\text { for counselling. } \\
\text { Use concepts from } \\
\text { proxemics. } \\
\text { Deal adequately with } \\
\text { different emotions. }\end{array}$ & $\begin{array}{l}\text { Expertise in communication } \\
\text { and organisation of training } \\
\text { in this area, facing the } \\
\text { difficulties in achieving } \\
\text { ethical and acceptable care } \\
\text { procedures. }\end{array}$ \\
\hline Patient-doctor relationships & $\begin{array}{l}\text { Establish good relations with } \\
\text { patients. }\end{array}$ & $\begin{array}{l}\text { Establish relations overtime using } \\
\text { patient-centred consultation models, } \\
\text { taking decisions and prioritizing } \\
\text { problems with respect for the } \\
\text { autonomy of the patient. }\end{array}$ & $\begin{array}{l}\text { Develop and maintain a } \\
\text { partnership with the patient. } \\
\text { Take into account } \\
\text { patients feelings, values } \\
\text { and preferences when } \\
\text { counselling, namely in the } \\
\text { complex areas of P4. }\end{array}$ & $\begin{array}{l}\text { Own and expand } \\
\text { an anthropological } \\
\text { understanding of patient- } \\
\text { doctor relationships, being } \\
\text { aware of subjectivity in the } \\
\text { medical relationship from the } \\
\text { doctors' side (self-awareness } \\
\text { on values, attitudes and } \\
\text { feelings) and using this } \\
\text { understanding to facilitate } \\
\text { patient's decisions. }\end{array}$ \\
\hline Advocate for the patient & $\begin{array}{l}\text { Capability to act as advocate for } \\
\text { the patient. }\end{array}$ & $\begin{array}{l}\text { Develop and maintain relationships } \\
\text { and communication styles actually } \\
\text { characterized by partnership with the } \\
\text { patient. }\end{array}$ & $\begin{array}{l}\text { Demonstrate active } \\
\text { advocacy, eventually } \\
\text { against third parties, } \\
\text { namely when dealing with } \\
\text { over-medicalization. }\end{array}$ & $\begin{array}{l}\text { Master skills in effective } \\
\text { leadership, negotiation and } \\
\text { compromising skills in order } \\
\text { to effectively influence the } \\
\text { health environment to protect } \\
\text { patients. }\end{array}$ \\
\hline
\end{tabular}

\begin{tabular}{|c|c|c|c|}
\hline & \multicolumn{3}{|c|}{ Practice environment } \\
\hline Domain & Novice & Competent & Proficient \\
\hline Patient safety & $\begin{array}{l}\text { Ensure highest standards of } \\
\text { patient safety at all times. }\end{array}$ & $\begin{array}{l}\text { Balance the needs of service delivery } \\
\text { with patients' needs. } \\
\text { Apply P4 to the practice environment. }\end{array}$ & $\begin{array}{l}\text { Develop P4 in the practice } \\
\text { environment to ensure } \\
\text { patient safety. } \\
\text { Involve patients as P4 } \\
\text { partners. }\end{array}$ \\
\hline
\end{tabular}

Ability to recognise early difficulties Awareness of potential impact on patient safety of problems in prevention activities. experienced by GPs in delivering P4. Respond to concerns raised about difficulties in prevention and seek further help, when necessary.

Actively involved in improving the awareness to $\mathrm{P} 4$, thus promoting excellent practice.
Manage complex difficulties in prevention and provide support to patients and GPS.

Respond to concerns raised, working within available systems of support. Identify problems of over-medicalization and improve measures trough

P4, assuring appropriate follow-up.

Identify problems and undertake remedial action when needed.
Organise P4 programmes for learners and colleagues. Have responsibility for overseeing the impact of P4 programmes on patient safety.

Ensure availability of support systems in the organisation either locally or within external sources.

Able to arrange and supervise remediation of problems identified by patients and GPs. Take overall responsibility for the quality and improvement of $\mathrm{P} 4$.

Ability to deal with complex quality improvement problems and supervise the application of appropriate solutions.

Source: elaborated by the authors from the professional standards for conservation, Institute of Conservation, London, 2008, based on the Dreyfus model of skil acquisition. ${ }^{21}$ 
Table 1. Continued...

\begin{tabular}{|c|c|c|c|c|}
\hline \multicolumn{5}{|c|}{ Information } \\
\hline Domain & Novice & Competent & Proficient & Expert \\
\hline Guidelines and Protocols & $\begin{array}{l}\text { Know guidelines and protocols } \\
\text { and carefully study them. }\end{array}$ & $\begin{array}{l}\text { Keep up-to-date about new guidelines } \\
\text { and protocols. } \\
\text { Compare them and evaluate whether } \\
\text { they are adequate in each individual } \\
\text { patient. } \\
\text { Apply them accordingly in } \\
\text { consultation. }\end{array}$ & $\begin{array}{l}\text { Discuss and compare new } \\
\text { guidelines and protocols } \\
\text { with peers and evaluate } \\
\text { the quality of evidence } \\
\text { on which they are based, } \\
\text { questioning the process of } \\
\text { their elaboration. } \\
\text { In consultation, favour the } \\
\text { use of symptom based } \\
\text { protocols. }\end{array}$ & $\begin{array}{l}\text { Understand that guidelines } \\
\text { aim to help make clinical } \\
\text { decisions, not to replace } \\
\text { them. } \\
\text { Establish the credibility } \\
\text { criteria of each guideline } \\
\text { before using or } \\
\text { recommending it. } \\
\text { Induce learners and } \\
\text { colleagues to understand } \\
\text { that not all documents } \\
\text { denominated as 'guidelines' } \\
\text { truly fulfil its task and that } \\
\text { the possibility of false- } \\
\text { positives or unnecessary } \\
\text { interventions grow when } \\
\text { applying the wrong protocol. }\end{array}$ \\
\hline Patient support and information & $\begin{array}{l}\text { Provide information to the } \\
\text { patients on basic P4 issues. }\end{array}$ & $\begin{array}{l}\text { Regularly update on problematic } \\
\text { issues (screening, medication, } \\
\text { procedures) and discuss those issues } \\
\text { with their patients in order to obtain } \\
\text { the better common decision. }\end{array}$ & $\begin{array}{l}\text { Understand the theoretical } \\
\text { frameworks which underlie } \\
\text { dealing with P4 in complex } \\
\text { situations and use it with } \\
\text { patients. } \\
\text { Take part in the } \\
\text { development of support } \\
\text { systems for patients. } \\
\text { Capable of responding to } \\
\text { special need of patients. }\end{array}$ & $\begin{array}{l}\text { Take responsibility for } \\
\text { providing information to } \\
\text { patients, both individually } \\
\text { and in groups. } \\
\text { Organise educational } \\
\text { learning/teaching } \\
\text { programmes about } \\
\text { screening, treatment, } \\
\text { procedures, disease- } \\
\text { mongering and quaternary } \\
\text { prevention. } \\
\text { Responds to patient's } \\
\text { questions eventually using } \\
\text { media. }\end{array}$ \\
\hline $\begin{array}{l}\text { Educational supervision and } \\
\text { support }\end{array}$ & $\begin{array}{l}\text { Self-motivated as potential } \\
\text { teacher/tutor/ } \\
\text { facilitator. }\end{array}$ & $\begin{array}{l}\text { Supervise a learner (student or } \\
\text { trainee) in areas of P4. } \\
\text { Able to give helpful and constructive } \\
\text { feedback to learners. } \\
\text { Provide a role-model. }\end{array}$ & $\begin{array}{l}\text { Supervise the clinical } \\
\text { performance and education } \\
\text { progress of an individual } \\
\text { learner (or groups). } \\
\text { Understand the theoretical } \\
\text { frameworks which underlie } \\
\text { dealing with P4 in complex } \\
\text { situations and use it with } \\
\text { learners. } \\
\text { Capable of responding to } \\
\text { trainees' special needs. }\end{array}$ & $\begin{array}{l}\text { Supervise whole programme } \\
\text { and individual elements } \\
\text { within it. } \\
\text { Supervise other teachers/ } \\
\text { trainers providing appropriate } \\
\text { feedback. } \\
\text { Give successful feedback } \\
\text { to learners with complex } \\
\text { difficulties, using outside } \\
\text { agencies where appropriate. } \\
\text { Take part in the development } \\
\text { of support systems for } \\
\text { trainers and trainees (or } \\
\text { other learners). }\end{array}$ \\
\hline
\end{tabular}

Source: elaborated by the authors from the professional standards for conservation, Institute of Conservation, London, 2008, based on the Dreyfus model of skill acquisition. ${ }^{21}$ 
Table 1. Continued...

\begin{tabular}{|c|c|c|c|c|}
\hline \multicolumn{5}{|c|}{ Science } \\
\hline Domain & Novice & Competent & Proficient & Expert \\
\hline Research & $\begin{array}{l}\text { Aware of the importance and } \\
\text { relevance of research. }\end{array}$ & $\begin{array}{l}\text { Participate in independent research } \\
\text { on request. } \\
\text { Acquainted with research being } \\
\text { carried out in their area of interest. }\end{array}$ & $\begin{array}{l}\text { Familiar with the important } \\
\text { relevant research findings. } \\
\text { Understand the techniques } \\
\text { of research relevant to } \\
\text { their role. } \\
\text { Able to develop and } \\
\text { conduct independent } \\
\text { research. } \\
\text { Awareness of possible flaws } \\
\text { in research. }\end{array}$ & $\begin{array}{l}\text { Experienced in conducting or } \\
\text { analysing research. } \\
\text { Supervise research projects, } \\
\text { establishing ground rules } \\
\text { for its independence from } \\
\text { industry. } \\
\text { Translate significant research } \\
\text { findings into P4 training } \\
\text { programmes. } \\
\text { Understand the role of } \\
\text { independent research in } \\
\text { protecting patients. }\end{array}$ \\
\hline EBM & Familiar to the concept of EBM. & $\begin{array}{l}\text { Have solid and updated knowledge of } \\
\text { scientific developments. } \\
\text { Currently make use of the best } \\
\text { evidence available when reaching } \\
\text { common decisions with their individual } \\
\text { patients. }\end{array}$ & $\begin{array}{l}\text { Apply the scientific method } \\
\text { consciously, explicitly and } \\
\text { judiciously, to medical } \\
\text { practice, including long- } \\
\text { established existing medical } \\
\text { traditions not yet subjected } \\
\text { to adequate scientific } \\
\text { scrutiny, providing the best } \\
\text { possible evidence- based } \\
\text { care. }\end{array}$ & $\begin{array}{l}\text { Have a deep knowledge of } \\
\text { EBM and tacit understanding } \\
\text { of its application across the } \\
\text { areas of medical practice. } \\
\text { Develop scientific } \\
\text { approaches to practice } \\
\text { through the active support of } \\
\text { initiatives in the area. } \\
\text { Proactivity in establishing } \\
\text { scientific programmes of } \\
\text { learning/teaching. }\end{array}$ \\
\hline Critical reading & $\begin{array}{l}\text { Have access to published data } \\
\text { and regularly read different } \\
\text { publications. }\end{array}$ & $\begin{array}{l}\text { Able to judge scientific publications, } \\
\text { to prioritize sources of information } \\
\text { and critically upraise different options } \\
\text { available. }\end{array}$ & $\begin{array}{l}\text { Able to adopt a critical and } \\
\text { research based approach to } \\
\text { practice and maintain this } \\
\text { through continuing learning } \\
\text { and quality improvement. }\end{array}$ & $\begin{array}{l}\text { Holistically grasp different } \\
\text { publications, moving easily } \\
\text { between intuitive and } \\
\text { analytical approaches. } \\
\text { Able to see overall "picture" } \\
\text { and possible alternatives, } \\
\text { while maintaining a critical } \\
\text { and sceptical approach. } \\
\text { Promote critical reading } \\
\text { among learners and } \\
\text { colleagues. }\end{array}$ \\
\hline Epidemiology & $\begin{array}{l}\text { Have knowledge of the } \\
\text { epidemiology of problems } \\
\text { presented by patients. }\end{array}$ & $\begin{array}{l}\text { Master an approach which allows easy } \\
\text { accessibility for patients and their } \\
\text { problems. } \\
\text { Have knowledge of the conditions } \\
\text { encountered in consultation and their } \\
\text { treatment. }\end{array}$ & $\begin{array}{l}\text { Skilled in acute, chronic, } \\
\text { palliative and emergency } \\
\text { care. } \\
\text { As prescribers, favour } \\
\text { approaches based upon } \\
\text { pharmaco-epidemiology } \\
\text { oriented towards the } \\
\text { patient. }\end{array}$ & $\begin{array}{l}\text { Use an organisational } \\
\text { approach to manage the full } \\
\text { range of health conditions. } \\
\text { Skilled in epidemiological } \\
\text { assessment and contribute } \\
\text { to the demystification of } \\
\text { market driven influences. }\end{array}$ \\
\hline
\end{tabular}

Source: elaborated by the authors from the professional standards for conservation, Institute of Conservation, London, 2008, based on the Dreyfus model of skill acquisition. ${ }^{21}$ 
Table 1. Continued...

\begin{tabular}{|c|c|c|c|c|}
\hline \multicolumn{5}{|c|}{ Science } \\
\hline Domain & Novice & Competent & Proficient & Expert \\
\hline Statistics & $\begin{array}{l}\text { Have basic knowledge in } \\
\text { statistics. }\end{array}$ & $\begin{array}{l}\text { Awareness of the use of surrogate } \\
\text { outcomes and relative instead of } \\
\text { absolute risk as a way to show } \\
\text { apparently favourable conclusions in } \\
\text { biased publications. }\end{array}$ & $\begin{array}{l}\text { Familiarity with common } \\
\text { misleading statistical errors, } \\
\text { such as regression to the } \\
\text { mean, the error of the } \\
\text { transposed conditional, and } \\
\text { the individual response. } \\
\text { Attentive to } \\
\text { lead-time bias, length bias } \\
\text { and over-diagnosis bias. }\end{array}$ & $\begin{array}{l}\text { Show authoritative } \\
\text { knowledge of statistics and } \\
\text { deep understanding across } \\
\text { areas of practice. } \\
\text { Ability to take responsibility } \\
\text { for going beyond existing } \\
\text { standards and creating } \\
\text { appropriate opportunities for } \\
\text { discussing and correcting } \\
\text { health plans or activities } \\
\text { based upon biased } \\
\text { conclusions. }\end{array}$ \\
\hline NNT/NNH & Know NNT and NNH. & $\begin{array}{l}\text { On their therapeutic activities always } \\
\text { take into account NNT and NNH, and } \\
\text { discuss it with their patients. }\end{array}$ & $\begin{array}{l}\text { Have broad access to NNT } \\
\text { and NNH discussions, } \\
\text { include them in all activities } \\
\text { and medical reasoning, and } \\
\text { influence others to being } \\
\text { aware of the importance } \\
\text { of these figures to clinical } \\
\text { decision. }\end{array}$ & $\begin{array}{l}\text { Create conditions in order to } \\
\text { widen the knowledge of NNT } \\
\text { and NNH. } \\
\text { Facilitate the access to } \\
\text { this kind of information, } \\
\text { by means of creating data } \\
\text { bases. } \\
\text { Collaborate in educational } \\
\text { activities towards learners, } \\
\text { colleagues and the public. }\end{array}$ \\
\hline \multicolumn{5}{|c|}{ Prevention } \\
\hline Domain & Novice & Competent & Proficient & Expert \\
\hline Underlying philosophy & $\begin{array}{l}\text { Awareness of prevention } \\
\text { fallacies. }\end{array}$ & $\begin{array}{l}\text { Awareness of the differences between } \\
\text { prevention and screening. }\end{array}$ & $\begin{array}{l}\text { Fully understand and } \\
\text { apply adequate criteria for } \\
\text { screening, sharing them } \\
\text { with learners and patients. } \\
\text { Critically oppose preventive } \\
\text { "crusades". }\end{array}$ & $\begin{array}{l}\text { Understand the ethical } \\
\text { dimensions of prevention. } \\
\text { Critically discuss with } \\
\text { learners, colleagues and } \\
\text { patient groups issues related } \\
\text { to: positive health, health } \\
\text { promotion, the inevitability } \\
\text { of death, prolongation } \\
\text { and quality of life, moral } \\
\text { influences. }\end{array}$ \\
\hline Preventive activities & $\begin{array}{l}\text { Have knowledge of preventive } \\
\text { activities practiced, including } \\
\text { P4. }\end{array}$ & $\begin{array}{l}\text { Critical about preventive activities } \\
\text { which are not evidence-based and } \\
\text { discuss them with their patients. }\end{array}$ & $\begin{array}{l}\text { While counselling, } \\
\text { display all information on } \\
\text { preventive activities. } \\
\text { Aware of the discussions } \\
\text { around preventive activities. } \\
\text { Familiarity with the practice } \\
\text { of P4. }\end{array}$ & $\begin{array}{l}\text { Experienced in P4 } \\
\text { approaches. } \\
\text { Organise and maintain } \\
\text { educational programmes on } \\
\text { P4, directed to learners and } \\
\text { colleagues. } \\
\text { Have an important role in } \\
\text { creating and displaying } \\
\text { information to the public on } \\
\text { P4 issues and collaborate } \\
\text { with groups of patients and } \\
\text { the communities in these } \\
\text { matters. }\end{array}$ \\
\hline
\end{tabular}

Source: elaborated by the authors from the professional standards for conservation, Institute of Conservation, London, 2008, based on the Dreyfus model of skill acquisition. ${ }^{21}$ 
Table 1. Continued...

\begin{tabular}{|c|c|c|c|c|}
\hline \multicolumn{5}{|c|}{ Prevention } \\
\hline Domain & Novice & Competent & Proficient & Expert \\
\hline Risk & $\begin{array}{l}\text { Understand the difference } \\
\text { between risk factors and } \\
\text { disease. }\end{array}$ & $\begin{array}{l}\text { Awareness of possible confusion } \\
\text { between risk factors and disease, } \\
\text { that patient might bring into the } \\
\text { consultation, which need clarification. }\end{array}$ & $\begin{array}{l}\text { Use of clear examples to } \\
\text { show to patients what are } \\
\text { risk factors and reassures } \\
\text { them by explaining the } \\
\text { probabilities associated } \\
\text { with those risk factors. }\end{array}$ & $\begin{array}{l}\text { Have long time experience } \\
\text { on demystifying risk factor- } \\
\text { based campaigns. } \\
\text { Able to organise information } \\
\text { in these matters and to } \\
\text { disseminate it to learners } \\
\text { and patient groups. }\end{array}$ \\
\hline \multicolumn{5}{|c|}{ Team } \\
\hline Domain & Novice & Competent & Proficient & Expert \\
\hline Team building & $\begin{array}{l}\text { Self-motivated as a potential } \\
\text { group leader. }\end{array}$ & $\begin{array}{l}\text { Capable of teambuilding, namely in } \\
\text { peer groups. }\end{array}$ & $\begin{array}{l}\text { Organise health team } \\
\text { groups, coordinate teams, } \\
\text { facilitate discussions, act as } \\
\text { group leaders. }\end{array}$ & $\begin{array}{l}\text { Coordinate groups, teams } \\
\text { and institutions, facilitating } \\
\text { discussion and harmonizing } \\
\text { procedures. } \\
\text { Organise learning/teaching } \\
\text { processes. }\end{array}$ \\
\hline Teamwork & Take part in peer groups. & Show skills in effective teamwork. & $\begin{array}{l}\text { Excellent in team working, } \\
\text { inspiring other members to } \\
\text { achieve objectives. }\end{array}$ & $\begin{array}{l}\text { Organise teamwork, actively } \\
\text { participate and trigger key } \\
\text { discussions. } \\
\text { Show contagious enthusiasm } \\
\text { and bring about all the } \\
\text { capacities of team members. }\end{array}$ \\
\hline \multicolumn{5}{|c|}{ Community } \\
\hline Domain & Novice & Competent & Proficient & Expert \\
\hline Patient group support & Awareness of patient groups. & $\begin{array}{l}\text { Communicate with patient groups, } \\
\text { namely through public health } \\
\text { conferences. }\end{array}$ & $\begin{array}{l}\text { Responsible for } \\
\text { communicating with } \\
\text { groups of patients involved } \\
\text { in centres' and regions' } \\
\text { coordination, and are } \\
\text { involved in P4 activities } \\
\text { within the community. }\end{array}$ & $\begin{array}{l}\text { Responsible for health } \\
\text { coordination's activities. } \\
\text { Organise, in collaboration } \\
\text { with peers, P4 activities } \\
\text { within the communities. } \\
\text { Collaborate with media in } \\
\text { informing the public about } \\
\text { health issues. }\end{array}$ \\
\hline Developing partnership & $\begin{array}{l}\text { Aware of the importance of } \\
\text { developing partnerships. }\end{array}$ & $\begin{array}{l}\text { Develop partnership between health } \\
\text { teams. }\end{array}$ & $\begin{array}{l}\text { Develop partnership } \\
\text { between health teams and } \\
\text { the community. }\end{array}$ & $\begin{array}{l}\text { Facilitate and organise the } \\
\text { development of partnerships, } \\
\text { assess them regularly and } \\
\text { assure the quality of the } \\
\text { work produced. }\end{array}$ \\
\hline
\end{tabular}

Source: elaborated by the authors from the professional standards for conservation, Institute of Conservation, London, 2008, based on the Dreyfus model of skill acquisition. ${ }^{21}$ 
Table 1. Continued...

\begin{tabular}{|c|c|c|c|c|}
\hline \multicolumn{5}{|c|}{ Clinical } \\
\hline Domain & Novice & Competent & Proficient & Expert \\
\hline Therapeutics & $\begin{array}{l}\text { Have deep theoretical } \\
\text { knowledge on therapeutics. }\end{array}$ & $\begin{array}{l}\text { Familiar with the management of } \\
\text { therapeutics, including drug and } \\
\text { non-drug approaches to treatment. }\end{array}$ & $\begin{array}{l}\text { Practice pharmacovigilance } \\
\text { oriented towards the } \\
\text { patient. } \\
\text { Show special attention } \\
\text { to age related and } \\
\text { co-morbidity problems } \\
\text { inducing polypharmacy, } \\
\text { as well as to critical } \\
\text { therapeutics. }\end{array}$ & $\begin{array}{l}\text { Have a deep understanding } \\
\text { of the problems underlying } \\
\text { polypharmacy and drug- } \\
\text { related effects on health. } \\
\text { Able to carefully and } \\
\text { critically assess the use } \\
\text { of drugs and their risk/ } \\
\text { benefit ratio - including } \\
\text { critical therapeutics - and } \\
\text { to organise information for } \\
\text { learners and colleagues. } \\
\text { When possible, use low } \\
\text { doses of well-known drugs, } \\
\text { when needed. }\end{array}$ \\
\hline Deprescription & $\begin{array}{l}\text { Have basic knowledge of the } \\
\text { process of deprescribing. }\end{array}$ & $\begin{array}{l}\text { Consider deprescribing in cases of } \\
\text { inappropriate polypharmacy in older } \\
\text { patients. }\end{array}$ & $\begin{array}{l}\text { Openly discuss benefit- } \\
\text { harm with patients to } \\
\text { consider deprescribing. } \\
\text { Target patients according } \\
\text { to highest risk of adverse } \\
\text { events and drugs more } \\
\text { likely to be non-beneficial. }\end{array}$ & $\begin{array}{l}\text { Aware of the multiple } \\
\text { barriers to deprescribing. } \\
\text { Access field-tested } \\
\text { discontinuation regimens } \\
\text { for specific drugs. } \\
\text { Foster shared education } \\
\text { and training in } \\
\text { deprescribing among all } \\
\text { members of the health care } \\
\text { team. }\end{array}$ \\
\hline Tests & $\begin{array}{l}\text { Have deep theoretical } \\
\text { knowledge on the use of tests. }\end{array}$ & $\begin{array}{l}\text { Master clinical skills in the use of } \\
\text { auxiliary tests, using them only when } \\
\text { supported by evidence and discussing } \\
\text { them with patients. }\end{array}$ & $\begin{array}{l}\text { Use evidence-based } \\
\text { tests when needed to } \\
\text { complement diagnosis. } \\
\text { Familiarity to sensitivity, } \\
\text { specificity, predictive values } \\
\text { and likelihood ratios of } \\
\text { auxiliary tests. }\end{array}$ & $\begin{array}{l}\text { Able to discuss among } \\
\text { peers on the indication for } \\
\text { tests. } \\
\text { Regularly update lists of } \\
\text { useful and non-useful tests. } \\
\text { Have experience in } \\
\text { explaining to the public the } \\
\text { reasons for or against the } \\
\text { use of an individual test. }\end{array}$ \\
\hline Disease-mongering & $\begin{array}{l}\text { Familiarity to disease- } \\
\text { mongering processes. }\end{array}$ & $\begin{array}{l}\text { Know about the "Market of Fear" and } \\
\text { explain it to their patients. }\end{array}$ & $\begin{array}{l}\text { Explain to their patients } \\
\text { and learners how over- } \\
\text { medicalization is achieved } \\
\text { through the creation or } \\
\text { invention of new (false) } \\
\text { diseases or the inflation of } \\
\text { old ones. }\end{array}$ & $\begin{array}{l}\text { Familiarity with the } \\
\text { literature on disease- } \\
\text { mongering and well } \\
\text { informed on the process. } \\
\text { Lobby, with peers, against } \\
\text { the medicalization of } \\
\text { life and death currently } \\
\text { occurring. } \\
\text { Influence learners, } \\
\text { colleagues and public on } \\
\text { the fight against disease- } \\
\text { mongering. }\end{array}$ \\
\hline
\end{tabular}

Source: elaborated by the authors from the professional standards for conservation, Institute of Conservation, London, 2008, based on the Dreyfus model of skill acquisition. ${ }^{21}$ 
Table 1. Continued...

\begin{tabular}{|c|c|c|c|c|}
\hline \multicolumn{5}{|c|}{ Clinical } \\
\hline Domain & Novice & Competent & Proficient & Expert \\
\hline Dying well & $\begin{array}{l}\text { Understand the limits to } \\
\text { how much medicine can } \\
\text { achieve. }\end{array}$ & $\begin{array}{l}\text { Attentive to exploitation of fears } \\
\text { regarding sickness and death and keen } \\
\text { to protect patients from this. }\end{array}$ & $\begin{array}{l}\text { Pay real attention, at } \\
\text { an individual level, to } \\
\text { the care of the dying, } \\
\text { keeping patients safe from } \\
\text { inadequate or useless } \\
\text { medical interventions. }\end{array}$ & $\begin{array}{l}\text { Understand the existential } \\
\text { challenges doctors face of } \\
\text { finding meaning in the face } \\
\text { of loss, suffering, and the } \\
\text { finitude of life, and discuss } \\
\text { it with learners. } \\
\text { Comprehend that doctors } \\
\text { don't show particular } \\
\text { aptitude towards mortality } \\
\text { of others and self, and } \\
\text { find ways to bridge the } \\
\text { gaps due to the very little } \\
\text { relevant education on these } \\
\text { subjects. }\end{array}$ \\
\hline
\end{tabular}

Source: elaborated by the authors from the professional standards for conservation, Institute of Conservation, London, 2008, based on the Dreyfus model of skill acquisition. ${ }^{21}$

\section{The methods: how we are going to teach?}

All teaching methods (Table 2), from traditional lectures to direct observation, can be useful, depending on the learners' stage and on the aims of the teaching session. Therefore, as learners progress in their learning journey towards expertise in quaternary prevention (as in other medical subjects), the teaching methods used can vary. They can be categorized by context: large/small groups; one-to-one; and self-directed study.

Table 2.Teaching Methods. ${ }^{22}$

\begin{tabular}{lll}
\hline \multicolumn{1}{c}{ Large/Small Group } & & \multicolumn{1}{c}{ One-to-one } \\
\hline Lecture & Direct observation & Reading \\
Workshop/Seminar & Video & Web based (e-learning) \\
Brainstorm & Simulated patients & Project based learning \\
Buzz group & Random/problem case analysis & Reflection \\
Games and exercises & Records review & Learning log \\
Group project based learning & Prescribing review & \\
Small group process work (Balint) & Medical audit & \\
Medical audit & Topic Tutorial & \\
Topic Tutorial & Role-play & \\
Role-play & & \\
Demonstration/practical skills teaching & & \\
\hline
\end{tabular}

Source: The EURACT/Leonardo Level 1. Course for teachers in Family Medicine, Module 3, "Teaching Methods". ${ }^{22}$

\section{Assessment and evaluation: how we will know that learning took place?}

There is a range of assessment methods which can be used to evaluate the acquisition of competences in the area of quaternary prevention, and/or to gauge if learning/teaching process has really occurred. The long list could include: (1) Case Based Discussion (CBD); (2) Consultation Observation Tools (COT); (3) Naturally Occurring Evidence (NOE); (4) Supervisor's Reports (CSR); (5) Patient Satisfaction Questionnaires (PSQ); (6) Performance Audit (PA); (7) Review of 
patient records (RPR); (8) Simulated patient (SP); (9) Standardized Patient (SP); (10) Role-playing; (11) Essay; (12) Group Discussion; (13) Chart Audit; (14) Written Case Report; (15) Mini-clinical-evaluation exercise (Mini-Cex); (16) Direct Observation of Practice Skills (DOPS); (17) Professionalism Mini-evaluation (P-Mex); (18) Video-observation of clinical encounters; (19) Peer assessment; (20) Multisource or 360 feedback (MSF); (21) Logbook; and (21) Reflective Portfolio.

Performance assessment should be embedded in the curriculum (for students or trainees) or in daily practice (for licensed doctors). Such programmes of assessment cannot be improvised and should be planned, prepared, implemented, evaluated and improved. ${ }^{23}$ When assessing the performance of quaternary prevention activities, appraisers are mostly dealing with workplace-based assessment. Therefore, it is advised to use the following methods as they are more effective (Table 3). ${ }^{24}$

Table 3. Overview of methods used to assess medical competence at the "does" level. ${ }^{25}$

\begin{tabular}{ll}
\hline Individual encounter methods & Direct performance measures \\
\hline Mini-clinical-evaluation exercise (Mini-Cex) & Assessment is confined to a single concrete situation \\
Direct observation of practice skills (DOPS) & Performance is assessed over a longer period of time \\
$\begin{array}{l}\text { Professionalism mini-evaluation (P-Mex) } \\
\text { Video-observation of clinical encounters }\end{array}$ & Aggregation methods \\
\hline Long-term methods & Continuous sampling of performance \\
\hline $\begin{array}{l}\text { Peer assessment } \\
\text { Multisource or } 360^{\circ} \text { feedback (MSF) }\end{array}$ \\
\hline Logbook \\
Reflective Portfolio
\end{tabular}

Source: based on EURACT Performance Agenda of General Practice/Family Medicine. Stefan Wilm, Ed. Düsseldorf University Press, Düsseldorf, 2014.

\section{The learning journey}

In order to easily demonstrate the progressive journey towards expertise in quaternary prevention, Figure 2 shows the Dreyfus model of skills acquisition which has a remarkable illustrative capability. ${ }^{23}$ The progression from novice to expert through the stages of competent and proficient usually happens in parallel with the evolution inside the profession from the medical student to the experienced doctor.

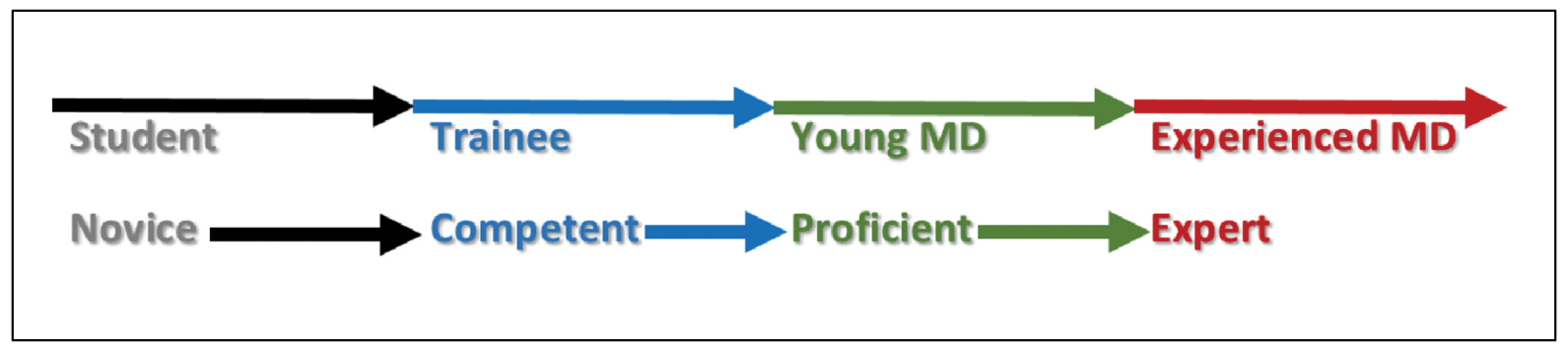

Figure 2. The learning journey. Source: Dreyfus, $1980 .{ }^{25}$

Even if there is not a biunivocal relation between medical student and experienced doctor, it is expectable to find proficiency and expertise more widely expanded in the latter. In fact, students deal mostly with knowledge and its application (KNOWS and KNOWS HOW, in Miller's Pyramid); trainees apply their multiple skills - communication, problem-solving, management - in a (more or less) protected environment (SHOWS); and full trained doctors (young or experienced doctors) fully exert their professional performance (DOES), hence, being able to bring quaternary prevention into the real world of their patients. ${ }^{24}$ 


\section{Conclusion}

The learning/teaching journey in quaternary prevention involves many skills. It is a complex field where epidemiology, communication, doctor-patient relationship, learning-centred approach, along with many others abilities are important topics that must be present in a balanced way. There are, however, 'risks along the road', the main one is the transformation of quaternary prevention in a simple political issue, instead of placing it as a practical and research medical field, which requires to be taught and learned.

Medical students often see "biological science" as separated from political or economic issues. ${ }^{11}$ The challenges of teaching quaternary prevention should not only integrate the "bio-psychosocial" or the holistic approach, but should also seek to integrate the macro and micro views of different areas such as economy, health services organisation and technological incorporation policies. The educational process within the field of quaternary prevention requires high level of teaching skills, mainly focused on andragogy. Efforts to enlighten the lay public on P4 subjects are extremely important and the trend is that, sooner or later, this issue will need to be addressed. The same need also applies to health professionals other than doctors.

\section{References}

1. Bean RB, Bean WB. Sir William Osler: aphorisms from his bedside teachings and writings. Springfield, IL: Charles C. Thomas; 1961.

2. Bentzen, N. Wonca dictionary of general/family practice wonca international classification committee. Copenhagen: Månedsskrift for Praktisk Lægegerning; 2003.

3. Jamoulle M, Roland M. Quaternary prevention. Hong Kong-Wonca Comitê de Classificação; 1995 july 6-9; Hong Kong, CN. Bruxelas: Research Group Fédération des Maisons Médicales; 1995. p. 6. [cited 2014 Nov 05]. Available from: http://hdl.handle.net/2268/173994

4. Brodersen J, Schwartz LM, Woloshin S. Overdiagnosis: how cancer screening can turn indolent pathology into illness. APMIS. 2014;122(8):683689. http://dx.doi.org/10.1111/apm.12278. PMid:24862511.

5. Kuehlein T, Sghedoni D, Visentin G, Gérvas J, Jamoule M. Quaternary prevention: a task of the general practitioner. Prim Care. 2010;10(18):350354.

6. Kopitowski KS. Prevención cuaternaria: se pueden y se deben limitar los daños por la actividad sanitaria. Rev. Hosp. Ital. B.Aires. 2013;33(3):90-95.

7. Welch HG, Black WC. Overdiagnosis in cancer. J Natl Cancer Inst. 2010;102(9):605-613. http://dx.doi.org/10.1093/jnci/djq099. PMid:20413742.

8. Jamoulle M. The four duties of family doctors: quaternary prevention: first, do no harm. Hong Kong Pract. 2014;36:46-49. [cited 2014 Nov 05]. Available from: http://hdl.handle.net/2268/170670

9. Gérvas J, Pérez Fernández M. Uso y abuso del poder médico para definir enfermedad y factor de riesgo, en relación con la prevención cuaternaria. Gac Sanit. 2006;20(3 Suppl):66-71. http://dx.doi.org/10.1157/13101092. PMid:17433203.

10. Moynihan R, Doran E, Henry D. Disease mongering is now part of the global health debate. PLoS Med. 2008;5(5):e106. http://dx.doi.org/10.1371/journal.pmed.0050106. PMid:18507498.

11 Skrabanek P, McCormick J. Follies and fallacies in medicine. 3rd ed. Eastbourne: Tarragon Press; 1998.

12. Gotzsche PG. Deadly medicines and organised crime: how big pharma has corrupted healthcare. London UK: Radcliffe Medical Press; 2013.13. Scott IA, Anderson K, Freeman CR, Stowasser DA. First do no harm: a real need to deprescribe in older patients. Med J Aust. 2014;201(7):390-392. http://dx.doi.org/10.5694/mja14.00146. PMid:25296059.

14. Heyrman J, editor. Educational Agenda, European Academy of Teachers in General Practice EURACT, Leuven 2004.

15. Başak O, Yaphe J, Spiegel W, Wilm S, Carelli F, Metsemakers JF. Early clinical exposure in medical curricula across Europe: an overview. Eur J Gen Pract. 2009;15(1):4-10. http://dx.doi.org/10.1080/13814780902745930. PMid:19229784.

16. Gaminde I, Hermosilla T. Quality related problems in clinical practice guidelines. Drug Ther Bull. 2012;20(1).

17. Stewart M, Brown JB, Weston WW, McWhinney IR, McWilliam CL, Freeman TR. Patient centered medicine: transforming the clinical method. 2nd rd. Abingdon: Radcliffe Medical Press; 2003.

18. Kleinman A. Patients and healers in the context of culture: an exploration of the borderland between anthropology, medicine and psychiatry. Lewiston, NY: University of California Press; 1981.

19. Knowle MS. The adult learner: a neglected species (1973). Houston: Gulf Publishing Company; 1990.

20. Starfield B, Shi L. Policy relevant determinants of health: an international perspective. Health Policy. 2002;60(3):201-218.

http://dx.doi.org/10.1016/S0168-8510(01)00208-1. PMid:11965331. 
21. The Institute of Conservation (ICON). Accreditation (PACR) and Professional Standards [Internet]. London: Institute of Conservation; 2008 [cited 2014 Nov 05]. Available from: http://www.icon.org.uk/index.php?option=com_content\&view=article\&id=5\&ltemid=6

22 Europen Academy Of Teachers in General Practice/Family Medicine (EURACT). Framework for continuing educational development of trainers in general practice in Europe (CEDinGP). Kraków, Poland: ZiZ Centrum Edukacji; 2012. 35 p.

23 Dreyfus S, Dreyfus H. A five-Stage model of the mental activities involved in directed skill acquisition. Washington, DC: Storming Media; 1980.

24. Miller GE. The assessment of clinical skills/competence/performance. Acad Med. 1990;65(9 Suppl):S63-S67. http://dx.doi.org/10.1097/00001888-199009000-00045. PMid:2400509.

25. Wilm S, editor. The EURACT performance agenda of general practice/family medicine. Düsseldorf: European Academy of Teachers in General Practice/Family Medicine (EURACT); 2014. 104 p. 